\title{
Morphological plasticity of corms in enhancing invasion of Chromolaena odorata
}

\author{
C. Joshi ${ }^{1}$, J. van Andel $^{2}$, A. Skidmore ${ }^{3}$, J. de Leeuw ${ }^{4}$ and I. V. Duren ${ }^{3}$
}

\begin{abstract}
In this paper, the researchers investigate the vegetative growth of Chromolaena odorata and the influence of light intensity on the understorey environment of Shorea robusta forest at Chitwan in south-central Terai, Nepal. C. odorata is a clonally growing shrub and typically consists of several clones with an underground "cormous organ" (a modified stem to store food reserve; here after "corm") belonging to an identical genet. In C. odorata, the biomass of such corms varied across the light gradient. The number of shoot demonstrated a strong logarithmic relation with biomass of corm. Under open forest canopy environment, corm biomass was strongly correlated with the number of shoots and the corm's age. However, under dense forest canopy, there was no significant relationship between corm biomass and its age. This result shows that corms of $C$. odorata were capable of maintaining their viability for a long period even under closed canopy environment. Any disturbances in forest canopy density would ultimately trigger its clonal growth capability. This plasticity of corms appeared to be a key strategy for invasion success of this species. Comparison of these results further indicates the importance of canopy density in determining invasion success of $C$. odorata.
\end{abstract}

Key words: Corm anatomy, "corm ring", Chromolaena odorata, clonal growth, invasion

The establishment of invasive plant species starts with the advent of propagules, typically in the form of seeds (Ridley, 1930). Once established, invaders attain local dominance through sexual or vegetative regeneration (Cousens and Mortimer, 1995). It has been repeatedly acknowledged that vegetative reproduction may be as valuable as seed production, as it makes the species less dependent on germination chance (Bunting, 1960). Vegetative growth facilitates the penetration into adjacent vegetation under more stressful conditions (de Antonio and Joshi, 1993).

Clonal growth is a common type of vegetative regeneration and dominant growth form in many ecosystems (Williams, 1975; Harper, 1977; Cook, 1983; Callaghan et al.,1992; Klimes et al., 1997). Clonal species penetrate into un-colonized areas through dispersal of stolons, rhizomes, tubers or corms (Klimes et al., 1997). Clonal growers are typically strong competitors (Auge and Brandl, 1997; Pysek, 1997). The combined ability of spreading and rising to dominance makes clonal growers invaders with a potentially strong influence on their direct adjacency. However, the role of clonal growth in invasiveness and invasibility has also been little explored (Shumway, 1995; Pysek, 1997).
Environmental conditions influence the production of clonal dispersal organs (de Kroon and Hutchings, 1995; Sachs and Novoplansky, 1997). Under suitable conditions, above-ground parts allocate resources to produce clonal reproductive organs. Individuals growing under less favourable environmental conditions may not be able to allocate sufficient resources. Hence, heterogeneity in environmental conditions might generate spatial variation in the relative growth rate of clonal reproductive organs (Hutchings and de Kroon, 1994; Hunt and Cornelissen, 1997). Spatial variation in environmental conditions are thus expected to result in spatial variability of the rates of clonal growth of plants, particularly when such factors are involved which influence their eco-physiology.

Native forest under-storey species live under shaded conditions. Opening of forest canopy, due to logging or natural disturbances results in increased light intensities inducing changes in species composition (Joshi et al., 2006 a). Typically, ruderal and heliophytic species rise to dominance when light intensity increases (Bayfield, 1980; Appleby, 1998; Kobayashi and Kamitani, 2000). A number of exotic plant species such as Chromolaena odorata have successfully established as invaders

\footnotetext{
${ }^{1}$ Embassy of Finland, Kathmandu, Nepal. E-mail: joshi@itc.nl

${ }^{2}$ University of Groningen, the Netherlands

${ }^{3}$ University of Twente, the Netherlands

${ }^{4}$ International Livestock Research Institute, Nairobi, Kenya
} 
under conditions of degraded canopy and forest clearing. Several of such clonal growers have been spreading vegetatively after initial establishment through seeds. The increased light intensities which postulates to trigger their rate of clonal growth.

The use of remote sensing has frequently been used to map invasive species. Applications have been restricted to localizing the distribution of invasive species (Everitt and Nixon, 1985; Ustin et al., 2002). It has been argued that it would also be useful to a manager to know where invasive species spread into unoccupied areas through sexual or vegetative reproduction. It is possible to map seed production of a forest under-storey species C. odorata (Joshi et al., 2006a), so far, no attempts have been made to map the rate of clonal growth in invaders.

Chromolaena odorata (L.) RM King and Robinson (King and Robinson, 1970) is one of the world's one hundred worst invasive species (ISSG, 2004). Originating from Central America, it now occurs in the humid tropics around the world (Muniappan and Marutani, 1988; Gautier, 1992b; Kriticos et al., 2005). It has a ruderal strategy and occurs in a wide range of environments including road verges, neglected agricultural fields and as an understorey species in forest. As a heliophyte (Gautier, 1992a), it requires sufficient light to grow and produce seeds (Witkowski and Wilson, 2001). Because of this characteristic, it becomes invasive in forest where the canopy has been broken up (de Rouw, 1991).
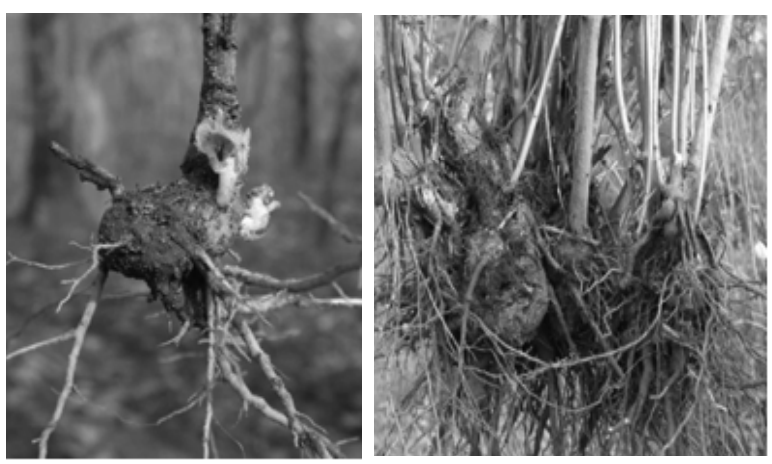

Fig. 1: Morphology of $C$. odorata consisting of a single clone (left) and a genet of multiple clones (right). Photos taken at start of the rainy season show the corm, previous seasons' and newly emerging shoots
C. odorata plants grows throughout the tropical areas of east and central Nepal (Joshi et al., 2006b) and are composed of one or more genetically identical clones (Fig. 1). Every clone has its own root system supported by corm (an underground swollen stem base specialized for food storage) from which shoots emerge (Fig. 1, left). Buds located belowground on the corm allow $C$. odorata to escape the dry season with its frequent fires. This strategy to escape the adverse season classifies C. odorata as a geophyte (Raunkiaer, 1937).

Single clone $C$. odorata plants develop into genets of multiple clones. After a number of years, clones begin to decay and split into two or more new clones at a spacing typically of $5 \mathrm{~cm}$ to 10 $\mathrm{cm}$ apart. As such, older plants consist of a dense crowd of clones together forming one genet that may reach up to several meters in diameter (Fig. 1 right). Stems of $C$. odorata grow up to $2 \mathrm{~m}$ in height.

In this paper, we investigated and model the biomass of corms of $C$. odorata to light intensity and corm age in Shorea robusta forests in southern Nepal. Corm age was established using "corm rings", which we described in this article. We next used remote sensing image to predict light intensity in the forest under-storey. Finally, we predict the spatial variation in clonal growth rate from the light intensity map.

\section{Materials and methods}

\section{Study area}

The study was executed in a tropical forest corridor, north of Chitwan National Park $\left(27^{\circ}\right.$ $31^{\prime}$ to $27^{\circ} 44^{\prime} \mathrm{N}$ and $84^{\circ} 24^{\prime}$ to $84^{\circ} 31^{\prime} \mathrm{E}$ ), 140 $\mathrm{km}$ south west of Kathmandu, Nepal. The forest was dominated by $S$. robusta, while the understorey was invaded by $C$. odorata.

\section{Data collection}

The study was conducted between 2003 and 2011. In 2003, 275 plots were visited to measure forest canopy density percentage and light intensity at $1.2 \mathrm{~m}$ above the ground using hemispherical photography taken with fisheye lens attached to a Nikon digital camera. In April-May, 2005, we collected 237 corms of $C$. odorata plants. The researchers measured the diameter of the corm and recorded the number of new shoots. The 
number of rings in the corm was counted on a transverse section. The corms were dried for 40 min in a microwave and dry biomass (g) measured. Out of those 237 plots, 26 plots of $5 \times 5 \mathrm{~m}$ were selected and marked as a permanent and visited every year between 2003 and 2011 in the months of September and October. Morphology and phenology of $C$. odorata were described following several years of intensive study of the species. Each year, the spatial spread of $C$. odorata was measured.

Meteorological data on the monthly maximum and minimum temperatures, relative humidity, precipitation and evapo-transpiration: recorded for an average of 36 years at Rampur weather station, were obtained from the Department of Meteorology, Government of Nepal.

\section{Anatomical analysis}

The anatomy of corms was further investigated at the Federal Research Centre for Forestry and Forest Products, Institute for Wood Biology and Wood Preservation, Hamburg, Germany. The anatomical structure of the xylem of the shoots and of the corms was investigated by light microscopy in order to prove the suitability of tree ring analyses for age determination in C. odorata. The shoot/corm was divided into segments each of $1 \mathrm{~cm}$ length. The samples were fixed in a FAA solution. The samples were embedded in polyethylene glycol (PEG 1500) with increasing concentration (PEG 1500:H2O, 1:2, 1:1, 2:1, 1:0, 1:0). For light microscopy and for the histometrical analyses of the xylem cells, transverse and radial sections $(10 \mu \mathrm{m})$ were prepared by a microtome (Reichert, Austria). For light microscopy, unstained and stained (safranine/ astrablue (1:1)) slides were used. Histometrical measurements were carried out with an image analyser.

\section{Data analysis}

Total light intensity was calculated from the digital hemispherical photographs using Gap light analyser software version 2 (Frazer et al., 1999; Frazer et al., 2001). For ANOVA, we classified the light intensity in the forest under-storey into three categories: high or full light (above $13 \mathrm{~mJ}$ $\mathrm{m}^{-2}$ day $^{-1}$, moderate light or semi-shade $(7-13 \mathrm{~mJ}$ $\mathrm{m}^{2}$ day-1) and low light or full shade (below $7 \mathrm{~mJ}$ $\mathrm{m}^{-2}$ day $\left.^{-1}\right)$.
We used two way ANOVA to investigate to what extent the biomass of $C$. odorata corm was related to light intensity and its age. We used curve expert (Hyams, 2005) to select the best fitting curve describing the relation between number of shoots and biomass of the corm.

\section{Mapping light intensity}

Field measurements on light intensity were combined with an ETM + image to produce a map of light intensity in the forest under-storey. A three-layer feed-forward back-propagation artificial neural network (ANN) consisting of an input, a hidden and an output layer was used for image classification (Skidmore et al., 1997). The Landsat ETM + image of October 24, 2001 was registered with sub-pixel accuracy $( \pm 17 \mathrm{~m})$. The first seven bands were used as input to the network. Light intensity calculated from the hemispherical photographs was used to train the ANN. The total data set of 275 samples was randomly divided into two groups. One subset of 138 samples was used for training and the other 137 samples for testing. The best results were obtained with a learning rate of 0.9 , a momentum of 0.7 and two hidden nodes. Finally 20 iterations of 7000 epochs were performed (the RMSE stabilized after approximately 7000 epochs) and the researchers selected the best classification based on least root mean square error (RMSE). Forest canopy density in percentage was also calculated using the same data set and procedure.

\section{Results}

\section{Climate and $C$. odorata phenology}

The season of heavy rainfall with precipitation higher than evapo-transpiration extends in southern central Nepal from July to September (Fig. 2) Significant rains may start in May and extend until November. The dry season extends from December to May. The season of active growth for $C$. odorata extends from May to October. Flowering starts in December and seeds ripen in February. After seed ripping, the stems die and drop off. Forest fire frequently destroys this decayed above-ground growth. New shoots develop from the resources stored in the corm in April, just before the start of the rainy season. If not destroyed by fire, old stems may persist. Old bushes thus form a tangled mass of old and new stems. 


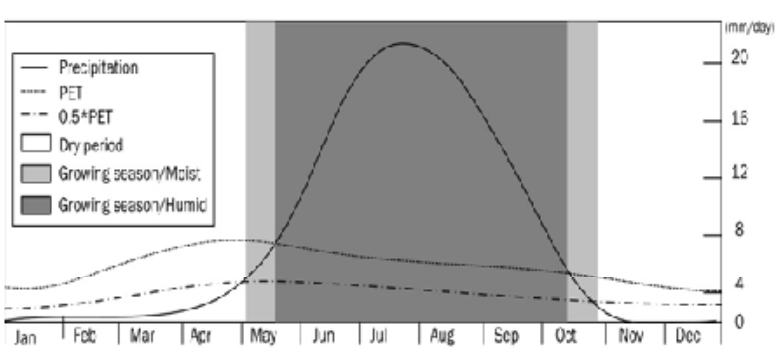

Fig. 2: Monthly mean (1968-2004) precipitation and temperature for Rampur station $\left(27^{\circ} 37^{\prime} \mathrm{N}\right.$, $\left.84^{\circ} 25^{\prime} \mathrm{E}\right)$. The numbers on the vertical line denotes degree Centigrade for the temperature (mean temp) and centimetres for mean precipitation, maximum precipitation, minimum precipitation and evapotranspiration for the curves.

\section{Corm anatomy}

Distinct increment zones were found in the xylem of the shoot and in the xylem of the corms of C. odorata. Increment zones in the xylem of $C$. odorata are labeled by fibres and ray parenchyma with reduced cell lumina as well as by wider rays (Fig. 3 a-c). The shoot/corm samples exhibited continuously developed increment zones (Fig. 3 b, d). Counting the number of increment zones found in the xylem at the shoot-root transition zone of plants of known age indicated the annual formation of "corm rings" in the xylem of $C$. odorata. Corm ring analyses showed that the oldest plants considered in this study had an age of 5 years. However, due to a very inhomogeneous pattern of ring width over the stem cross section and along the corm axis, a corm ring analysis was not suitable to quantify the biomass allocation in the corms on an annual scale.

\section{Corm and shoot dynamics}

The maximum age of corms observed under full light was five years. Parts of these corms had decayed, leaving fragmented living tissue supporting vital shoots. Maximum observed corm age under full shade was also five years. However, these corms looked rotten, with little live tissue remaining.

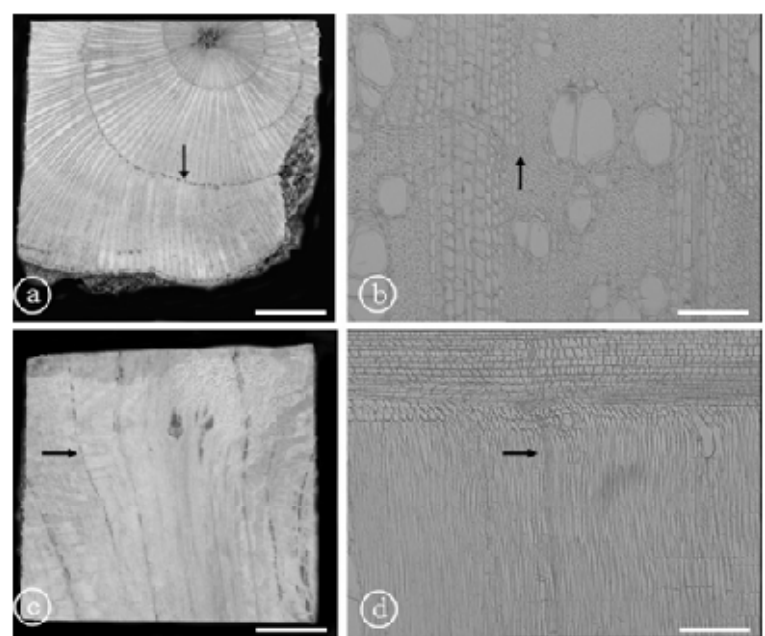

Fig. 3: Cross sections (a/b) and radial sections (c/d) of the xylem of corm of $C$. odorata (sample 107). Increment zones (arrows) are labelled fibres and ray parenchyma with reduced cell lumina and dark stained accessory compounds within (ray parenchyma). Scale bars: $(\mathrm{a} / \mathrm{c})=500 \mu \mathrm{m},(\mathrm{b} / \mathrm{d})=100 \mu \mathrm{m}$.

Figure 4 shows corm biomass in relation to age and light intensity. Log transformation was used because it equalized group standard deviations, which originally varied by more than an order of magnitude. The figure suggests that corm biomass increases when plants age under full light or semi shaded conditions, but not under full shade.

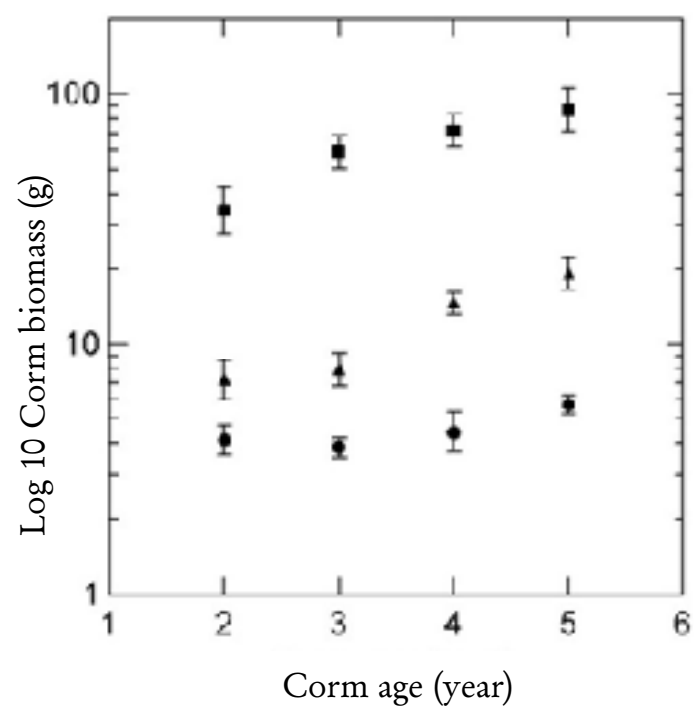

Fig. 4: Corm biomass in relation to age of $C$. odorata and light intensity: $\boldsymbol{\square}=$ full light, $\Delta=$ semi-shade, $\bullet=$ full shade.

This was confirmed by analysis of variance. Both light and corm age had a highly significantly effect. The significant interaction implied that 
the increase of corm biomass with age changed with light intensity. While corm biomass differed significantly between two, three, four and five year old plants in the semi-shade (one-way ANOVA; $\mathrm{p}=0.000)$ and in full sun-shine $(\mathrm{p}=0.003)$, it did not in the full shade $(\mathrm{p}=0.22)$. Hence, corms do apparently not grow in full shade while they do under semi shaded and lighter conditions.

One might expect that larger corms support larger plants. Figure 5 reveals that the number of shoots (y) produced by of C. odorata increased with the biomass of its corm (x). The relation was best described by the following Horel model (Equation 1), that explained $82 \%$ of variation in shoot number:

$y=2.501 * 1.001^{x *} x^{0.266}$

(Equation 1)

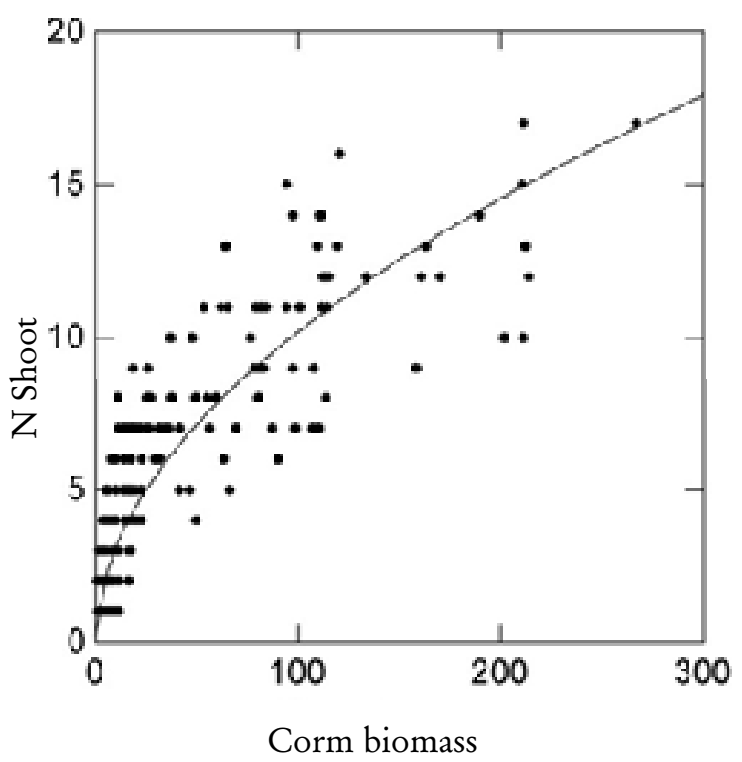

Fig. 5: Relation between corm biomass (g) and number of shoots produced by $C$. odorata.

If low light constrains the growth of corms and subsequently shoot numbers, one would expect no enlargement of shoot numbers over time under low light conditions. Figure 6 reveals that this is the case indeed. The annual rate of increase of shoot numbers was significantly related to light conditions. Number of shoots increase with age only under semi shaded or full light conditions. ANOVA analysis conformed that there is no significant difference in shoot numbers between two, three four and five year old shaded plants. While number of shoots differed significantly between two, three, four and five year old plants in the semi-shade (one-way ANOVA; $\mathrm{p}=0.000$ ) and in full sun-shine $(\mathrm{p}=0.000)$, it did not in the full shade $(p=0.29)$. These results indicate that number of shoots almost not increase in plants growing in the shade. It does increase for plants growing under semi-shade and full sunshine.

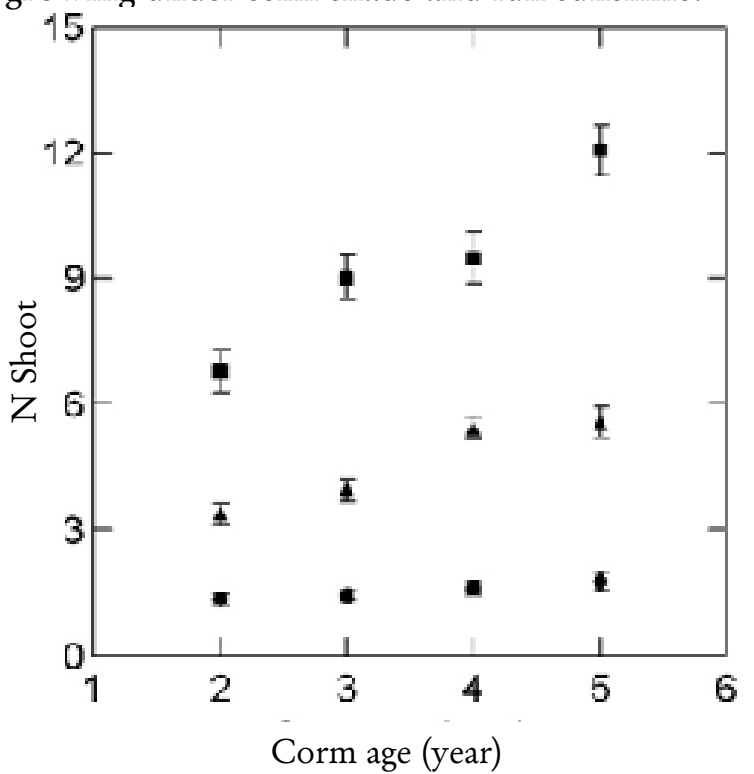

Fig. 6: Relation between shoot number in relation to plant (corm) age and light intensity: $\square=$ full light, $\Delta=$ semi-shade, $\bullet=$ full shade in $C$. odorata.

\section{Mapping forest under-storey light intensity}

Figure 7 presents the performance of the artificial neural networks in scatterplots of observed versus predicted light intensity and the map produced by ANN classifier. It revealed that the prediction of light intensity by the artificial neural network was unbiased. The t-statistic of the slope (b) and intercept (a) reveal that these did not differ significantly from 1 and 0 respectively $(\mathrm{a}=-0.002, \mathrm{SE}=0.005, \mathrm{t}=-0.361$, $\left.\mathrm{b}=1.003, \mathrm{SE}_{\mathrm{b}}=0.035, \mathrm{t}_{\mathrm{b}}=0.086, \mathrm{r}^{2}=0.81\right)$.

\section{Spatial prediction of rate of clonal growth of} C. odorata

Number of shoots per year produced by the plant was utilized for spatial prediction of rate of clonal growth of $C$. odorata. The relation was best described by the following modified power model (Equation 2) which explained $73 \%$ of variation in clonal growth rate:

$\mathrm{y}=0.251 * 2.258^{\mathrm{X}}$

(Equation 2) where, $\mathrm{Y}$ is rate of clonal growth and $\mathrm{X}$ is light intensity. 


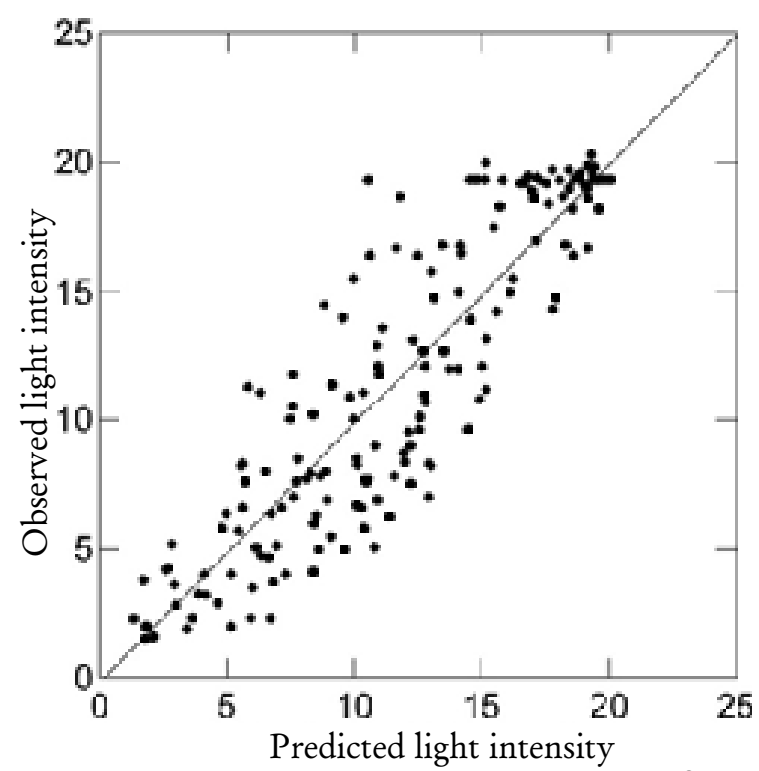

Fig. 7: Scatterplot of light intensity $\left(\mathrm{mJ} / \mathrm{m}^{2} /\right.$ day $)$ reaching the forest floor observed in the field, against the predicted light intensity derived from a classification of a Landsat ETM+ image

We inverted this model to predict rate of clonal growth of $C$. odorata in the Chitwan region of Nepal. Map (Fig. 8) revealed that the current clonal growth rate of $C$. odorata was high along the forest edge and road, however, it has a high potential to substantially increase its range towards forest interior. It could potentially invade large areas of the forest interior which are climatically suitable for clonal growth in terms of size and number of corms as well as increase in occupied areas by stems.

\section{Discussion}

The results presented in this study indicate that light intensity controls the growth of the corms of $C$. odorata. The study results further reveal that the size of the corms determines the number of next seasons' shoots. Plants growing under full light conditions thus enlarge their canopy, which in turn allows them to allocate more resources to the corm, which next year produces an even larger canopy. This positive feedback loop continues for a maximum of five years, after which the clone splits in two or more offspring starting the cycle anew. Over time, this leads to continuous enlargement of $C$. odorata genets.

The study results reveal by contrast, that plants growing under shaded conditions do not enlarge their corm. Consequently, their number of shoots remains stagnant and hence no enlargement takes place. The researchers' observation on the decaying condition of five-year old corms under shaded conditions suggests that they probably succumb within five years. The fact multiclone genets were never observed under shaded conditions fits into this picture.

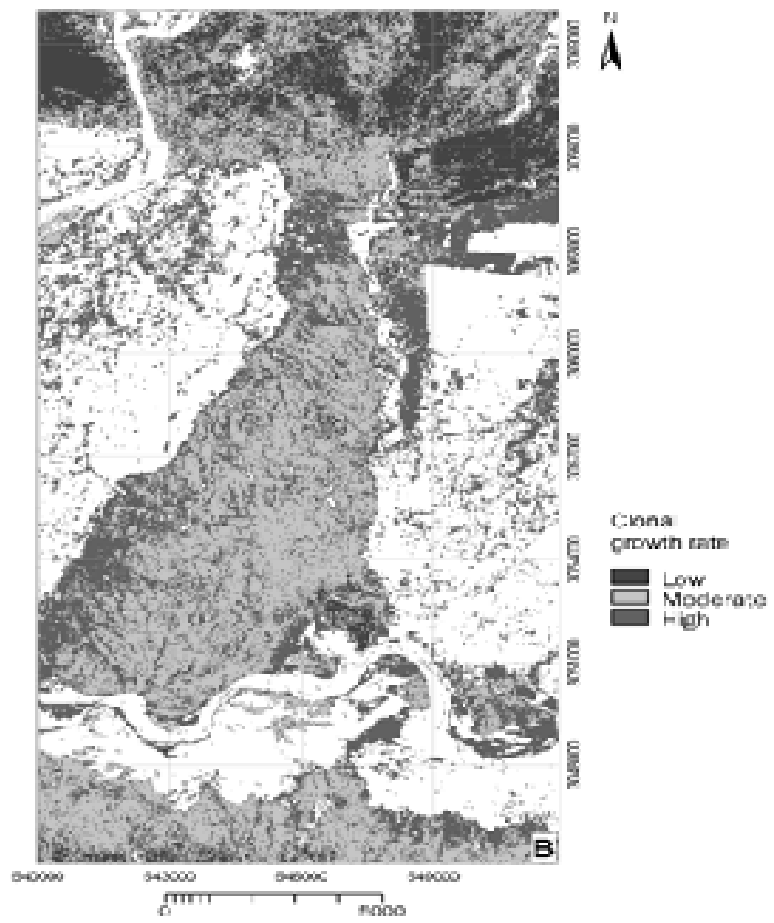

Fig. 8: Potential clonal growth rate of C. odorata.

C. odorata thus manages to grow vegetatively under medium to full light conditions. These conditions rarely exist in natural forest. In forests, under shaded conditions one expects $C$. odorata populations to consist of young single clone genets, which is indeed the case. Under canopy openings however, $C$. odorata would receive sufficient light for vegetative expansion. Conditions of canopy opening widely occur in $S$. robusta forests in the Nepalese Terai. Not surprisingly, C. odorata populations here consist of multi-clonal genets, sometimes several meters in diameter. Figure 9 summarizes the effect of light intensity at different stages of the development of $C$. odorata linking to clonal growth and its vegetative invasion.

What makes $C$. odorata such a successful invader in the $S$. robusta forests of the Nepalese Terai? C. odorata invades through its huge production of achenes, and its corm production and vegetative spreading were promoted by human disturbances 
through altering forest under-storey light regime (opening up of forest canopy that benefit its competition and dominance among native plant communities). Furthermore, deliberate fire destroys native vegetation and most of the upper parts of C. odorata bush, leaving the basal stem unaffected. These stems regenerate shoots in the rainy season enabling the species to become the first dominant in the next growing season (Liggitt, 1983) Grazing on neighbouring plant species further enhances its clonal growth by reducing inter-specific competition as the leaves and young shoots of $C$. odorata are poisonous to livestock (Sajise et al., 1972).

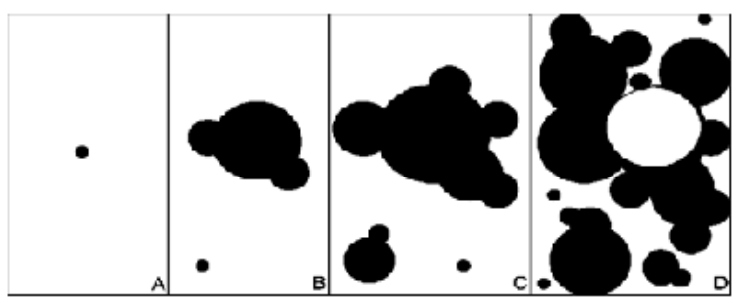

Fig. 9: Spatial and temporal dynamics of corm of C. odorata under high light environment. A) An establishment of a mother corm in a new environment by long or short distance seed dispersal. B) Development and growth of daughter corms. C) Growth and range expansion of daughter corms of the identical genet. D) Death of mother corm and range expansion of new daughter corm populations.

Clonal reproduction in many species is determined by physical factors such as light, moisture nutrient availability or distance related seed dispersal mechanisms. Spatial distribution of these factors are increasingly available or can be mapped using remote sensing (Robinson and Valentine, 1979; Dennis and Brusven, 1993; Austin et al., 1996; Stone et al., 1997; Baker et al., 2000, Corsi et al., 2000, Guisan and Zimmermann, 2000; Kerr and Ostrovsky, 2003). The present study showed how these physical factors, may linked to map the clonal growth rate of an invasive species.

Comparisons of the traits of different invaders suggest that some species are more invasive in a particular environment than others. A wide range of species traits may underline these differences, including ruderal nature, wide seed dispersal mechanism, producing large amount of seeds, or allocation of resource during favourable conditions or long survival in the system (Grime, 1979; Richardson and Bond, 1991; Roche et al., 1997). All these characters interact with each other and with the environmental factor making it difficult to identify the cause of invasiveness in individual cases. However, this study's results show the primary importance of biomass allocation in $C$. odorata in determining spatial patterns of vegetative reproduction along light gradients.

\section{Conclusion}

C. odorata's ability to store energy enhances the early clonal growth in the next growing season. This competitive ability appears to be an important key to understanding its behaviour as an invader. If openings present in a stand, $C$. odorata becomes established and outcompetes previously established native species.

Incorporation of remote sensing techniques with species biometry yield instantaneous, useful, cost effective, multi-scale and temporal information on clonal growth dynamics of an invasive species. Mapping clonal growth rate in $C$. odorata population could significantly reduce control cost by allowing one to concentrate control efforts to manage habitats so as to curtail the spread of invasive species. Mapping the rate of clonal growth could be well applied to other invasive species. In this respect, the immediate benefit of this research has been to contribute to the knowledge base of land managers by providing improved information on the rate of spatial and temporal spread of clonal population C. odorata, which will support efficient habitat ranking to restore invaded areas and protect non-invaded ecosystems.

\section{References}

Appleby, M. W. A. 1998. The incidence of exotic species following clear felling of Eucalyptus regnans forest in the Central Highlands, Victoria. Australian Journal of Ecology 23:457465.

Auge, H., and Brandl, R. 1997. Seedling recruitment in the invasive clonal shrub, Mabonia aquifolium Pursh (Nutt.). Oecologia 110:205-211.

Austin, G. E., Chris, J. T., Houston, D. C. and Thompson, D. B. A.1996. Predicting the distribution of buzzard Buteo buteo nesting 
area using a geographical information system and remote sensing. The J. of Applied Ecology 33:1541-1550.

Baker, R. H. A., Sansford, C. E. C., H. Jarvis, Cannon, R. J. C. MacLeod, A. and Walters, K. F. A. 2000. The role of climatic mapping in predicting the potential geographical distribution of non-indigenous pests under current and future climates. Agriculture, Ecosystems and Environment 82:57-71.

Bayfield, N. G. 1980. Replacement of vegetation on disturbed ground near Ski Lifts in the Cairngorm Mountains, Scotland. Journal of Biogeography 7:249-260.

Bunting, A. H. 1960. Some reflections on the ecology of weeds. In The Biology of Weeds (ed.) Harper, J. L. Blackwell Scientific Publications, Oxford, UK, 11-26.

Callaghan, T. V., Jonsdottir, I. S., Carlsson, S., Svensson, B. M. and Jonasson, S. 1992. Clonal plants and environmental change: introduction to the proceeding and summaries. Oikos 63:341-347.

Cook, R. E. 1983. Clonal plant populations. American Scientist 71:244-253.

Corsi, F., de Leeuw, J. and Skidmore, A. K. 2000. Modeling species distribution with GIS. In Research Techniques in Animal Ecology (eds.) Boitani, L. and Fuller, T. K. Colombia University Press, New York., USA, 389434

Cousens, R., and Mortimer, M. 1995. Dynamics of Weed Populations Cambridge, UK.

de Antonio and Joshi C. M. 1993. Mechanisms controlling invasion of coastal plant communities by the alien succulent Carpobrotus edulis. Ecology 74:83-95.

de Kroon, H. and Hutchings, M. J. 1995. Morphological plasticity in clonal plants: the foraging concept reconsidered. $J$. of Ecology 83:143-152.

de Rouw, A. 1991. The invasion of Chromolaena odorata (L.) King \& Robinson (ex Eupatorium odoratum), and competition with the native flora, in a rain forest zone, south-west Cote d'Ivoire. J. of Biogeography 18:13-23.
Dennis, J. F., and Brusven, M. A.1993. Spatial analysis of grasshopper density and ecological disturbance on southern Idaho rangeland. Agriculture, Ecosystems and Environment 43:31-47.

Everitt, J. H., and Nixon, P. R. 1985. Using color aerial photography to detect camphorweed infestations on South Texas rangelands. Photogrammetric Engineering and Remote Sensing 51:1793-1798.

Frazer, G. W., Canham, C. D. and Lertzman. K. P. 1999. Gap Light Analyzer (GLA) Version 2.0.In Imaging Software to Extract Canopy Structure and Gap Light Transmission Indices from True-colour Fisheye Photographs, Users Manual and Program Documentation. Simon Fraser University, Burnaby, British Columbia and the Institute of Ecosystem Studies, Millbrook, New York, USA.

Frazer, G. W., Fournier, R. A., Trofymow, J. A., Hall, R. J. 2001. A comparison of digital and film fisheye photography for analysis of forest canopy structure and gap light transmission. Agricultural and Forest Meteorology 109:249-263.

Gautier, L. 1992a. Contact foret-savane en Cote D'Ivoire centrale: Role de Chromolaena odorata dans la dynamique de la vegetation. $\mathrm{Ph} \mathrm{D}$. Universite de Geneve, Geneve.

Gautier, L. 1992b. Taxonomy and distribution of a tropical weed: Chromolaena odorata (L.) R. King \& H. Robinson. Candollea 47:645662.

Grime, J. P. 1979. Plant Strategies and Vegetation processes. John Wiley \& Sons, Chichester, UK.

Guisan, A. and Zimmermann, N. E. 2000. Predictive habitat distribution models in ecology. Ecological Modelling 135:147-186.

Harper, J. L. 1977. Population Biology of Plants. Academic Press, London, UK.

Hunt, R., and Cornelissen, J. H. C. 1997. Components of relative growth rate and their interrelations in 59 temperate plant species. New Phytologist 135:395-417. 
Hutchings, M. J., and de Kroon, H. 1994. Foraging in plants: the role of morphological plasticity in resource acquisition. Advances in Ecological Research 25:159-238.

Hyams, D. G. 2005. Curve expert. in. http:// curveexpert.webhop.net/, Hixson, USA.

ISSG. 2004. http://www.issg.org/database. In Global Invasive Species Database, Auckland, New Zealand.

Joshi, C., de Leeuw, J., van Andel, J., Skidmore, A.K., Lekhak, H.D., van Duren, I.C., Norbu, N.2006a. Indirect remote sensing of a cryptic forest understorey invasive species. Forest Ecology and Management 225 (1-3): 245 - 256.

Joshi C., de Leeuw, J. and Skidmore A.K. 2006b. Upscaling species invasion patterns from local to regional for forest ecosystem management. ISPRS mid term symposium: "Remote sensing: from pixel to processes", Commission VI, WG VI/7; 8-11 May 2006, the Netherlands. Kays, S., and Harper J. L. 1974. The regulation of plant tiller density in a grass sward. J. of Ecology 62:97-105.

Kerr, J. T., and Ostrovsky, M. 2003. From space to species: ecological applications for remote sensing. Trends in Ecology and Evolution 18:299-305.

King, R. M., and Robinson, H.1970. Chromolaena odorata (L) King and Robinson. Pbytologia 20:204.

Klimes, L., Klimesova, J., Hendriks, R. and van Groenendael, J. 1997. Clonal plants architecture: a comparative analysis of form and function. In The ecology and evolution of clonal plants. (eds.) de Kroon, H.and van Groenendael, J. and Backhuys, Leiden, The Netherlands, 1-29

Kobayashi, M., and Kamitani, T. 2000. Effects of surface disturbance and light level on seedling emergence in a Japanese secondary deciduous forest. J. of Vegetation Science 11:93100.
Kriticos, D. I., Yonow, T. and Mcfadyen, R. E. 2005. The potential distribution of Chromolaena odorata (Siam weed) in relation to climate. Weed Research 45:246-254.

Liggitt, B. 1983. The invasive alien plant C. odorata, with regard to its status and control in Natal. Monograph. Institute of Natural Resources, University of Natal, Pietermaritzburg, South Africa.

Muniappan, R., and Marutani, M. 1988. Ecology and distribution of $C$. odorata in Asia and the Pacific. In Proceedings of the First International Workshop on Biological Control of Chromolaena odorata, Bankok, Thailand, 22

Pysek, P. 1997. Clonality and plant invasions: can a trait make a difference? In The Ecology and Evolution of Clonal Plants, (eds.) de Kroon, $\mathrm{H}$. and van Groenendael, J. and Backhuys, Leiden. The Netherlands, 405-427

Raunkiaer, C. 1937. Plants Life Forms. The Clarendon Press, Oxford, UK.

Richardson, D. M., and Bond, W. J. 1991. Determinants of plant distribution: evidence from pine invasions. American Naturalist 137:639-668.

Ridley, H. N. 1930. The Dispersal of Plants Throughout the World. L. Reeve and Co., Ashford, Kent, UK.

Robinson, J. V. and Valentine, W. D. 1979. The concepts of elasticity, invulnerability, and invadability. J. Theoret. Bio. 81:91-104.

Roche, C. T., Thill, D. C. and Shafii, B. 1997. Reproductive phenology in yellow starthistle (Centaurea solstitialis L.). Weed Science 45:763-770.

Sachs,T. and Novoplansky, A. 1997. What does a clonal organization suggest concerning clonal plants? In The Ecology and Evolution of Clonal Plants. (eds.) de Kroon, H.. van Groenendael, J. and Backhuys, Leiden, The Netherlands, 55-77

Sajise, P. E., Palis, R. K., Norcio, N. V. and Lales, J. S. 1972. Chromolaena odorata imperils grassland. Pasture Newsletter 1:1-2. 
Shumway, S. W. 1995. Physiological integration among clonal ramets during invasion of disturbance patches in a New England salt marsh. Annals of Botany 76:225-233.

Skidmore, A. K., Turner, B. J., Brinkhof, W. and Knowle, E. 1997. Performance of a neural network: mapping forests using remotely sensed data. Photogrammetric Engineering and Remote sensing 63:501-514.

Stone, K. D., Heidt, G. A., Caster, P. T. and Kennedy, M. L.1997. Using geographic information systems to determine home range of the Southern Flying Squirrel (Glaucomys volans). American Midland Naturalist 137:106-111.
Ustin, S. L., DiPietro D., Olmstead, K., Underwood, E. and Scheer, G. 2002. Hyperspectral remote sensing for invasive species detection and mapping. International Geoscience and Remote Sensing Symposium 24th Canadian Symposium On Remote Sensing, Toronto, Canada.

Williams, G. C. 1975. Sex and Evolution. Princeton University Press, Princeton, USA.

Witkowski, E. T. F. and Wilson, M. 2001. Changes in density, biomass, seed production and soil seed banks of the non-native invasive plant, Chromolaena odorata, along a 15 year chronosequence. Plant Ecology 152:13-27. 